\title{
The Needs of Intelligent Information and Media Education for Students of Higher Education Institutes: the Sociological Aspect
}

\author{
Alla Lobanova ${ }^{1, *}$ Aleksandra Kuzior ${ }^{2}$ Yana Zoska ${ }^{3}$ Yuriy Viznytsia ${ }^{1}$ \\ Anna Kochmanska ${ }^{2}$ Olena Komarova ${ }^{1}$ \\ ${ }^{I}$ Department of Sociology and Mass Communications, Kryvyi Rih State Pedagogical University, Ukraine \\ ${ }^{2}$ Department of Applied Social Sciences, Silesian University of Technology, Poland \\ ${ }^{3}$ Department of Philosophy and Sociology, Mariupol State University, Ukraine \\ ${ }^{*}$ Corresponding author. Email: lobanova-as@ukr.net
}

\begin{abstract}
In the article the actual modern problem that is pervasive minutes informatization of modern life, including the education system, which is not only positive but also negative effects on young people. The concept "reasonable information needs" is introduced into scientific circulation and the author's understanding of its content, essence, structure, principles, and factors is substantiated. Attention is focused on the need, in terms of the unauthorized and unlimited influence of information content, including fake and manipulative nature, on the minds of young people, including students, the introduction and improvement of media education in all institutions of higher education. Its purpose, functions, role in the formation of reasonable information needs of students of higher educational institutions of both humanitarian and technical profile of Ukraine and Poland are considered.
\end{abstract}

Keywords: informatization of modern life, information content, reasonable information needs, media education.

\section{INTRODUCTION}

In recent years, in both the Polish and Ukrainian educational space in connection with the development of information technology, the problem of the growing information needs of students has become relevant. This necessitates the diagnosis of these needs and, in accordance with the results obtained, the introduction of new educational courses that would meet today's global challenges. The COVID-19 pandemic has also dramatically affected the information needs of higher education seekers, changing their content pyramid compared to the pre-quarantine period.

It is no coincidence that of the most urgent social and popular discipline in modern educational space is media education, as well as gained weight in the global value as an answer to accelerated development of information technology. As a global trend, media education began to develop in the United States, Great Britain and European countries: France, Germany, Sweden, and others; it began to be introduced into educational programs in the second half of the last century.

Meanwhile, in Poland and Ukraine, the public demand for the development of media education became clear only at the beginning of the current century. All spheres of society have become saturated with information technology, the media sphere has undergone rapid modernization, and numerous communications have become more intense and complex. Of course, that information technology in recent decades has radically affected the personal and social life, filling it with new forms of communication - social networks and diverse media content. And the continuous growth of the media, on the one hand, ensures the effectiveness of information relations in society, which is constantly complicated, promotes comprehensive human self-realization in society and in the global information system, and on the other rapidly changes the structure of information needs of various social groups, that make them continuously gain new expertise and technology they use. 
At the present stage of active digitalization, virtualization of Polish and Ukrainian society, multimedia technologies and content, strengthening of manipulative technologies in the media, the issues of further development of media education have gained wide scientific resonance and increased attention from education workers and scientists. In this regard, there are several important questions to which we seek to find answers in this scientific work: what is the structure or pyramid of information needs of modern students? What factors shape the information needs of students? What is media education and how does it affect the information needs of students in modern conditions?

Is it possible to talk about reasonable information needs and what is the role of media education in their formation? The research on reasonable answers to the questions are not possible without the results of sociological research, which will help to solve the important sociological problem, which is the insufficient influence of modern media education in the formation of intelligent information needs of young people, including total informatization and digitalization of society. This is the relevance of this work. Therefore, the purpose of this work is to scientifically substantiate the content of the concept "reasonable information needs", verify the results of empirical research among students of higher education and to discuss the feasibility of improving media education as an important factor in shaping information literacy and competence of modern students.

\section{2. "INTELLIGENT INFORMATION NEEDS" - THE CONTENT, NATURE, AND STRUCTURE OF THE THESAURUS}

Needs are the basis of personal development and in a broad sense are those forms of human interaction with the world around us, through which its physiological, social, intellectual, and spiritual reproduction takes place. At the heart of almost all scientific explanations of human needs is General notes a known structure of motivational needs A. Maslow, which distinguishes five levels: physiological, existential, social, The required prestigious and self-actualization needs. "The dominant goal monopolizes consciousness and in some way stimulates and organizes the various abilities of the organism needed to achieve it. Less urgent needs are minimized or even forgotten and denied" [1].
The need to meet human needs at any level objectively actualizes the emergence of information needs. The needs of the individual motivate him to seek relevant information, to identify ways of satisfying a particular need. Thus, in our opinion, information needs are a mandatory component of human needs at any level. As L.V. Konoval notes, "if living organisms feel the need for information to meet relatively simple vital needs, the information needs (IN) of humans are much more complex, they cover all social information circulating in society" [2].The search for the content of information needs is usually carried out by scientists in the field of informatics, as well as employees of news agencies or library structures, because it is important for them to know and understand their consumer and fully meet his needs for information necessary for his life. There are different interpretations of information needs as a scientific category. In a broad sense, information needs are the needs of a person in the information that will enrich him with new knowledge about a particular subject or area of his life's attention. As A.M. Panina rightly emphasizes, information needs "can be expressed either in the form of oral or written information requests or in certain consumer behavior in relation to potential sources of information (other people, literature, media, etc.)" [3].

It is clear that information needs, unlike others, have their own specifics, because in the process of meeting them "the object of consumption, ie information, not only is not destroyed but, conversely, on its basis, new information arrays are formed for consumption. This is the fundamental difference between information as a resource and other resources created by nature and man" [2]. P. Borlund and $\mathrm{N}$. Pharo in their article "A need for information on information needs" presented the results of a study on their own methodology of information needs of students and teachers, as well as undergraduate and graduate students and clarified their structure. In particular, based on samples of 87 real information needs, they concluded that information needs belong to three different areas (work, study and personal interest); serve ten different types of goals (decide between two or more alternatives, make decisions that affect your personal life, make decisions that will change your life; find inspiration for something you want to achieve; find information that supports you in your hobby / leisure; learn something new about a phenomenon; plan a vacation trip; compare prices, quality, etc. to buy something; miss time; and write assignments, reports). Meanwhile, P. Borlund and $\mathrm{N}$. Pharo began their article with the idea that "the concept of information needs remains insufficiently 
studied" and concluded: "therefore, the information about information needs is needed" [4].

Therefore, information needs are realized by searching for and inventing the necessary information that satisfies their subject and helps to solve a certain need. Meanwhile, the modern world is so oversaturated with information that, unfortunately, it is often impossible to find the necessary information at once, as it is necessary to review dozens and hundreds of other information messages. It can be argued that today the media and the Internet are oversaturated with disinformation which is very difficult to find the information you need today. The users, immersed in the media-network world, delve into the information network, forgetting about the main motive that prompted them to access the Internet. This gradually leads to Internet addiction, which later becomes an obsession to search for any information or message every minute.

Obviously, in such a situation it makes sense to talk about the need to form in consumers of mass media reasonable information needs. And for this it is necessary, at least, to understand their content, essence, structure, principles, and factors influencing their formation. This concept is not found in the reference and scientific literature known to us, although the concept of "reasonable needs" is common.

In the encyclopedic literature, reasonable needs are considered as "individual needs that have a positive social and personal significance", are rationally and morally justified, and socially sanctioned. "Accordingly, unreasonable needs - needs that lead to the primitivization of the individual and even to its degradation" [5]. As noted by O.O. Stashkevych, the criterion for dividing needs into reasonable and irrational is rationality, and therefore "reasonable needs correspond to scientific ideas about the consumption of goods and services necessary to maintain a healthy lifestyle, personal development. Irrational needs beyond reasonable, become hypertrophic and sometimes perverted forms" [6].

As we can see, the generic concept that determines the explanation of the content and essence of the concept "reasonable information needs" is "mind". This means that reasonable are the needs of the individual in the necessary information, which he is aware of, meet certain personal and social goals, are socially significant and useful for his selfdevelopment, social relationships, and social behavior. The main purpose of these needs may be to obtain new necessary knowledge for the realization of personal interests, which are associated with the satisfaction of reasonable needs. Since the "reasonableness" in the broad sense needs associating with the values of a healthy lifestyle, especially, the "Information reasonable and needs an" expedient to connect, firstly, to search for the information that will facilitate healthy lifestyle; secondly, with the avoidance of consumption of disinformation which is imposed by the media and the Internet, and, thirdly, the formation of the ability to recognize manipulative fake information, which is oversaturated in the media and, fourth, the ability to implement successful life strategies related to obtaining useful information. Hence, intelligent information needs to be based on the following principles as a meaningful choice, rationality, personal advisable, sufficient, usability and benefit.

So the essence of intelligent information needs lies in their intelligence and rationality, that means conscious choice of the consumer media and Internet networks for personal development, adult limit their use in the process of obtaining information and the ability to separate true information content from untrue information garbage (fakes, manipulative technologies, etc.). Thus, structurally reasonable information needs consist of the subject-consumer and the purpose (goals) of his consumption of information, conscious interests in obtaining certain information, his ability to recognize true and fake information, the ability to limit themselves in the consumption of information content. There are many factors shaping the information needs of young people - the whole media space, including the Internet, as well as almost all socialization agents: family, school, friends, universities, but to form reasonable information needs of students, we believe, can only media education.

As T. Wilson rightly points out, the search for determinants related to information needs to be expanded to include various aspects, including the socio-cultural and physical environment [7]. Of course, the most favorable socio-cultural environment for the formation of reasonable information needs is the educational space. Thus, in secondary schools, one of the factors in the formation of reasonable information needs is STEM-education (Science, Technology, Engineering, Math) - a series of courses or training programs that prepare students for successful employment, for after-school education or both, requires different and more technically complex skills, in particular with the application of mathematical knowledge, scientific concepts and information skills and technologies. According to O.V. Kurnosenko, the introduction of STEMeducation allows students to form the most important characteristics that determine the future competent 
specialist: the ability to see the problem comprehensively; ability to formulate a research question and ways to solve it; flexibility as the ability to understand a new point of view and resilience in defending one's position; originality of thinking, departure from the template; ability to regroup ideas and connections; ability to abstract or analyze; ability to concretize or synthesize; a sense of harmony in the organization of the idea [8]. However, the most important factor in the formation of reasonable information needs in students, we believe, is exclusively media education, the first step to which is STEM-education.

\section{MEDIA EDUCATION AS A FACTOR IN THE FORMATION OF INTELLIGENT INFORMATION NEEDS OF STUDENTS}

Scientific research in the field of media education began in the early ' 60 s of the 20 century. Thus, D. Bachynsky draws attention to the fact that the first curriculum in media education was developed by Canadian scientist Marshall McLuhan in 1959 and was actively used in the United States and some European countries [9]. Meanwhile, there is another opinion. The "media education' term was defined by the International Film and Television Council in 1973 as the study, teaching and learning of modern methods of communication and expression considered to be part of a specific and autonomous discipline in pedagogical theory and practice as opposed to their use as teaching and learning auxiliaries in other areas of knowledge, such as mathematics, science and geography. This definition was appropriately completed and strengthened by an expert meeting convened at Unesco in 1979 which took the view that the concept of media education covered all ways of studying, learning and teaching at all levels (primary, secondary, higher, adult education, lifelong education) and in all circumstances, the history, creativity, use and evaluation of media as practical and technical arts, as well as the place occupied by media in society, their social impact, the implication of media communication, participation, modification of the mode of perception they bring about, the role of creative work and access to media [10]. Since then, media education has become the subject of research by many scholars. In their works considered the evolution, structure, international experience, and practical prospects of media education, ways of acquiring and requirements for media literacy and media competence, the problems of its introduction in educational institutions $[11 ; 12]$.
The intensification of scientific research of Ukrainian teachers in the field of media education has led to an increase in attention to it by state educational institutions. It is no coincidence that the Concept of Media Education Implementation came into force in 2010, which aimed to "promote the development of an effective media education system in Ukraine to ensure comprehensive preparation of children and youth for safe and effective interaction with the modern media system, media awareness, and media literacy, and media competence according to their age and individual characteristics" [13]. In April 2016 the Presidium of the National Academy of Educational Sciences of Ukraine approved already new its wording, which Senior and met and defined as promoting the development of such a system of media education, which had become the "foundation of humanitarian security, development, and consolidation of civil society, combating external information aggression comprehensive preparation of children and youth for safe and effective interaction with the modern media system, the formation of citizens' media literacy and media culture in accordance with their age, individual and other characteristics" [14].

Of course, the entry of higher education in Ukraine into the European educational space requires appropriate and adequate steps to implement European educational standards in the Ukrainian education system. Media and education are one of the top priorities, because the modern information space, having a globalization scale, at the same time has its risks associated with a variety of manipulative information technologies that often distort real public life. Media education, of course, can reduce information risks, and therefore its activation is an important state strategy. As the review of the scientific literature and in many countries of the world media education part of the contents of general and professional training of young people, with the aim to give it knowledge of the positive and negative aspects of the modern information world, the skills of analytical thinking versatile for meaning, purpose and its end result of the flow of information, ability to resist manipulative application of information communication and technologies and. As noted by O.O. Demyanenko, media education, from the beginning of its formation (the 60s of the 20 century) was called to help subjects to adapt to the world of media culture, to master the language of mass media (media), to learn to analyze media texts, and now it is seen as "direction in the field of education, which explores the patterns of media influence on the individual, the impact of different types of information 
on the education and upbringing of pupils, students and other subjects of study, as well as their willingness to apply new technical means in practice" [10].

Of course, in recent decades, the rapid development of information technology has significantly affected the media (tools and devices for creating, storing, duplicating information; means and channels of broadcasting, distribution, presentation of communication content) and unrecognizably changed people's lives and the nature of their communications. Rapid penetration of Internet technologies (in 2019 93.4\% are Ukrainian Internet users [15], including $71 \%$ of the population are regular Internet users (use 1 per month or more) [16], compared of $2002-5.2 \%$ of the population [17], and in $2000-0.4 \%$, respectively [18]) acted as an effective tool of influence on the fast (fundamental, radical) transformation of media space not only in the real world but also in the virtual world, the expansion of "hot" and "cold" means of communication [19, p. 28] and convergent media, which combine several formats simultaneously.

In fact, these two worlds - real and virtual, began to exist in parallel, intersecting, complementing each other, and influencing the social behavior of people. Analysis of communicative interaction in media space clearly highlights these changes - essentially the role of digital media against the background of rapidly falling consumer information printed and audio media (Table 1 [17, pp. 562-563; 20, p. 539; 21, pp. 498, 483-485]).

Table 1. Dynamics of consumption of media in Ukraine 2000-2018 biennium ( $n=1800$ respondents are representative by gender and age).

\begin{tabular}{|l|c|c|c|c|c|}
\hline Media consumption & 2000 & 2002 & 2010 & 2013 & 2018 \\
\hline Use of the Internet & - & 5.2 & 35.6 & 57.4 & 89.6 \\
\hline Watching TV shows & 86.5 & 76.5 & 86.6 & 81.0 & 65.7 \\
\hline $\begin{array}{l}\text { Reading newspapers, } \\
\text { magazines }\end{array}$ & 70.3 & 61.2 & 51.9 & 47.7 & 29.8 \\
\hline $\begin{array}{l}\text { Listening to radio } \\
\text { programs }\end{array}$ & 58.2 & 43.6 & 32.7 & 32.6 & 22.8 \\
\hline Visiting cinemas & 1.4 & 2.0 & 4.7 & 12.8 & 7.2 \\
\hline Listening to music & 34.5 & 22.0 & 26.0 & 39.1 & 23.2 \\
\hline
\end{tabular}

The presented table shows that the participatory media sphere in Ukraine provides young people, in particular students, with many opportunities to use communication tools to obtain information.

Students' use of the Internet to obtain information is almost three times higher than their use of print media and four times higher than listening to radio programs. With the availability of the Internet, the need for students to visit cinemas has decreased almost 10 times.

Thus, according to surveys of students of 28 educational institutions of Ukraine conducted by sociologists of the Classical Private University (Zaporizhzhya) in 2019 (sample $n=690$ ), the activity of Internet use among young people is much higher than representatives of other age groups (Table 2).

Table 2. The activity of Internet use by representatives of different age groups (in \%) (Ukraine)

\begin{tabular}{|l|c|c|c|}
\hline Internet usage & $\begin{array}{c}\text { up to } 35 \\
\text { years }\end{array}$ & $\begin{array}{l}35-54 \\
\text { years }\end{array}$ & $\begin{array}{c}55 \text { years } \\
\text { and older }\end{array}$ \\
\hline Almost every day & 93 & 84 & 22 \\
\hline 1-2 times in a week & 3 & 6 & 12 \\
\hline 3-4 times in a month & 0 & 1 & 1 \\
\hline Do not use at all & 4 & 9 & 65 \\
\hline
\end{tabular}

No less important indicators are the duration and contextuality of Internet use. During the survey it was established, that nearly a quarter of the student spends more than 8 hours a day on the Internet (Table 3).

Table 3. Distribution of respondents' answers (in\%) about the continuous use of the Internet per day (Ukraine)

\begin{tabular}{|l|c|}
\hline time of constant Internet use per day & $\begin{array}{c}\text { answers } \\
\text { (in \%) }\end{array}$ \\
\hline over 8 hours & 26 \\
\hline 6-8 hours & 19 \\
\hline 4-6 hours & 20 \\
\hline 2-4hours & 10 \\
\hline 1-2hours & 7 \\
\hline from 15 minutes to 1 hour & 11 \\
\hline less than 15 minutes & 7 \\
\hline
\end{tabular}

The data in Tables 2 and 3 show that for almost all young people, including those seeking higher education, the Internet is a daily tool for obtaining information, with $75 \%$ of them using it for 6 hours or more, and a third of them - more than 8 hours a day.

The range of young people's satisfaction with the needs of the Internet is quite wide, as shown in Table 4.

It can be stated that the digital communicative space of the Internet allows satisfying many information needs, in particular, such as:

- information, knowledge, and implementation of lifelong learning in today's requirements for flexibility and constant adaptation change jobs and professions, new skills, acquisition of which allows have a permanent job; 
- establishing a set of temporary connections, contacts for and implementation of professional activities;

- communication in interactions in building interpersonal relationships;

- providing self-branding in (self-presentation, designing social identity) to present the status and social position identification of the person;

- e-commerce (purchasing goods and services) $[22$, p. 64-67].

Table 4. Frequency of meeting different needs using the capabilities of the Internet (distribution is given in $\%)(n=690)$ (Ukraine)

\begin{tabular}{|c|c|c|c|c|}
\hline $\begin{array}{l}\text { The range of } \\
\text { needs }\end{array}$ & Constantly $\mid c$ & Often & |Rarely $\mid$ & Never \\
\hline Listening to music & 28 & 39 & 27 & 6 \\
\hline $\begin{array}{l}\text { Watching movies } \\
\text { and TV series }\end{array}$ & 30 & 43 & 22 & 4 \\
\hline $\begin{array}{l}\text { Communicate with } \\
\text { friends and / or } \\
\text { family via } \\
\text { messengers, chats } \\
\end{array}$ & 49 & 38 & 11 & 2 \\
\hline $\begin{array}{l}\text { Use of websites in } \\
\text { social networks }\end{array}$ & 36 & 39 & 22 & 3 \\
\hline Doing homework & 45 & 37 & 14 & 5 \\
\hline $\begin{array}{l}\text { Use of electronic } \\
\text { courses }\end{array}$ & 24 & 31 & 33 & 11 \\
\hline I play games online & 9 & 11 & 27 & 53 \\
\hline $\begin{array}{l}\text { Expansion of } \\
\text { knowledge within } \\
\text { interests, hobbies }\end{array}$ & 27 & 38 & 26 & 8 \\
\hline $\begin{array}{l}\text { Use of online } \\
\text { stores, auctions }\end{array}$ & 6 & 15 & 39 & 40 \\
\hline $\begin{array}{l}\text { Preparation for } \\
\text { tests, audience }\end{array}$ & 18 & 34 & 29 & 19 \\
\hline $\begin{array}{l}\text { View news, read } \\
\text { articles }\end{array}$ & 29 & 42 & 23 & 6 \\
\hline Using e-mail & 30 & 37 & 28 & 5 \\
\hline $\begin{array}{l}\text { Arranging official } \\
\text { affairs and / or } \\
\text { paying bills, etc. } \\
\end{array}$ & 12 & 21 & 37 & 29 \\
\hline \begin{tabular}{|l|}
$\begin{array}{l}\text { Communication } \\
\text { with teachers }\end{array}$ \\
\end{tabular} & 19 & 35 & 35 & 11 \\
\hline $\begin{array}{l}\text { Maintain your own } \\
\text { blog, fan page or } \\
\text { website } \\
\end{array}$ & 9 & 13 & 31 & 48 \\
\hline \begin{tabular}{|l|} 
View and / or \\
participate in forum \\
discussions
\end{tabular} & 6 & 11 & 33 & 51 \\
\hline $\begin{array}{l}\text { Creating graphics, } \\
\text { music, movies, } \\
\text { photo processing } \\
\end{array}$ & 9 & 15 & 32 & 44 \\
\hline $\begin{array}{l}\text { Expanding the } \\
\text { knowledge needed } \\
\text { for learning }\end{array}$ & 30 & 39 & 23 & 8 \\
\hline
\end{tabular}

According to A. Yu. Ishchenko, with the development of media education, its initial "precautionary" paradigm, which was based on moralideological and theoretical-communicative approaches, is gradually changing to pragmaticresearch: in the relevant training courses of developed countries, more emphasis is not placed on the dangers of the media and related "manipulative technologies", and the ability to effectively use the capabilities of traditional and modern media, although ethical and ideological elements also retain their representation" [23].

For this reason, the introduction of media education in the educational process in Ukraine was based on the creation of such training programs on media literacy and media competence, which would help prepare young people for: the perception of information; awareness of language and the real content of the presented information; development of skepticism, skills of empirical study; formation of knowledge and skills to critically evaluate the information content; understanding the context (sociocultural, political) of media functioning; conscious choice and broadcast of media cultural tastes; weighted first approach to enhance their participation in the municipal communications; opposition to the flow of manipulative information technologies that negatively affect their consciousness. The formation of media literacy and media competence within the study of the course on media education is the basic principle of forming reasonable information needs of higher education students and thus raising the level of their media culture.

The educational process in the country's educational institutions for the last 20 years has been saturated with computer equipment for more advanced teaching and learning, thus providing an opportunity for pupils and students to intensify methods of mastering not only the exact sciences but also the humanities. Passing exams, tests, tests, and independent work, using a variety of information platforms, such as Moodle, during the quarantine activities associated with the Covid-19 pandemic, has become a daily practice in schools. On the one hand, this greatly facilitates the work of teachers, but on the other hand, it requires an increase in computer literacy and teachers. The particularly acute problem of improving media education emerged from the time the annexation of Crimea and Russia start of military conflict on Eastern Ukraine (March-April 2014) when the Russian Federation started an undeclared hybrid war against Ukraine. The American military expert Keir Giles argues that the concept of hybrid warfare has existed for a long time, but some aspects of it may 
be new shapes, such as cyber-attacks or the use of social media [24]. This means that in the modern information space, the content of mass media and information technologies that they use to influence the mass consciousness is radically changing. As T. Popova, an expert on strategic communications of the Public Association "Information Security", rightly remarks: "Unfortunately, new technologies do not always have an exclusively positive dimension for human progress. History gives us many examples when advanced achievements were very quickly transformed into weapons and other means of violence. Today, politicians are often forced to use terms such as "new generation wars", "hybrid war", "fourth generation of wars", "information confrontation". It is obvious that in such circumstances there are many who want to transfer the armed conflict to the information space in general and social networks in particular" [25].

It was during hybrid warfare call people to consciously hone important information to protect themselves from manipulation by modern media that information weapons dangerous as well as traditional, very important. For example, Ukrainian researchers A. Stadnyk and S. Shcherbyna point out the importance of the "News Literacy" course created by the Ukrainian TV channel " $1+1$ " for the realization of the educational goal and the spread of media literacy among the population. This course is aimed at explaining to the population the following issues: what are the professional standards, ethical dilemmas, how media can manipulate public opinion through news, who are the main media owners in Ukraine, how social networks change the perception of news [26, p. 35]. Due to changes in the content of media content in terms of total information society and long-term hybrid warfare, of course, it needs to clarify its purpose, tasks I and content of media education.

As G.V. Onkovych emphasizes, media education is "a direction in pedagogy aimed at studying mass communication and information nature of the media (press, television, radio, cinema, video, etc.) and principles their use for actualized mastery of the basics of knowledge" [27, p. 29]. But at the same time, media education should focus not only on studying the nature of the media but also on understanding the nature and nature of social contacts, relationships, relationships, i.e. social communications that are formed in the media space, including the threat they hide not only on a national but also on a global scale. After all, the reality has become the use of social networks for psychological influence on the mass consciousness of various social groups, communities, incitement to mass strikes, disobedience, opposition to legitimate authorities, destabilization in the country, or support or resolution of armed conflicts. Yes, experts have reason to say that approximately $8-15 \%$ of Twitter accounts and 5 to $11 \%$ on Facebook are regular bots, and researchers from Cardiff University ("Cardiff University" - one of the leading universities in the UK) have demonstrated the ability to predict mass actions and other events much faster than the police with an advance of up to one hour [25].

Thus, users of social networking are powerful are active initiators and drivers of various social events direction and content - political, environmental, economic, cultural, ethnic, international, military, etc. This means that the web is, now, (according to the study, as of 2018) covers the world about 4 billion users, of which more than 3 billion users of social networks, particularly in Ukraine - 25.6 million internet users ( $58 \%$ of the total population), 13 million of them use social networks, 9.5 million - mobile phones for communication on the Internet, is becoming an increasingly influential media platform for the formation of local and global online societies that can significantly influence government and international processes [28]. These facts indicate that due to the rapid development of Internet communications and social networking media education should focus not only on the study of the content of media content but also in its social in the directional list, i.e. social causes and consequences that result from its formation and influence on the mass consciousness and social behaviour of local and global communities.

After all, this is the social essence of media content - speaking in the language of the socio-dramaturgical approach of I. Hoffman - it is formed by interested actors who try to solve personal or group (often custom) social (social) problem (task) through social networks (or mass media). As networks are always interested users (ACT viewers), which outlined the problem gets personal about her weight and significance, and therefore an urgent solution. So they deliberately attached to virtual and then real community and a network, thereby giving consent to participate in sharings social actions. In recent years, there are many facts, as is social networking intensified protests of various social groups and strata of the population in Ukraine and across Europe. Suffice it to mention the protests of the "yellow vests" in France (end of 2018) against rising fuel prices, protests against the introduction of the land market in Ukraine.

There is another side to this problem, namely the lack of necessary information for young people and 
students. Research by the CEDOS think tank shows that universities publish very little information about their educational programs. This is confirmed by the majority of students - 59\% lacked some information about universities when they were elected. The lack of information on employment prospects $(22 \%)$, bases and opportunities for practice (18\%), international exchange programs $(16 \%)$, and information on the content of programs and disciplines (15\%) received the most answers to the multiple questions. At the same time, $41 \%$ of students said that they had all the necessary information about universities when they were elected. It seems that in some cases there is a vicious circle where students often do not create a demand for information and universities are in no hurry to publish it. Regarding the multiple nature of the lack of information when choosing a specialty, almost a quarter of students (24\%) said that they did not receive the desired information about the demand for the profession in the labor market; wanted to, but could not find out about the possible salary $-18 \%$. In general, $62 \%$ of surveyed students lacked some information about the specialty [29].

This makes it necessary for universities that want to better inform entrants about themselves, more actively use their pages on the Internet, and post there enough relevant information. It is also necessary to systematically involve one's own students in information campaigns, to initiate the creation of a sufficient number of individual student pages on social networks, to help saturate them with interesting live information about the university.

Therefore, the social essence of media content should be reflected in information technology and the concept of media education. According to L. Masterman, the central and unifying concept of media education is "representation, ie not a reflection of reality, but its representation, and the main goal "denaturalization" of the media" [30, p. 40-42]. That media education is primarily a research process that develops critical thinking and used as an analytical and tool for understanding reality. This and other principles of media education are reflected in the theories of media education. Ukrainian scientists V. Ivanov, O. Voloshenyuk, L. Kulchytska are summarized the basic theory of media education. These include researchers-educators include eight theories of media education: ideological (media manipulates public opinion in the interests of certain classes, races, and nations); protectionist (injectable, protective - protection from the harmful effects of the media); sources of meeting the needs of the audience (helping students to use the media to maximum effect); practical (or media education as a multiplication table
- automatic ability to work with media); aesthetic or artistic (helping the audience to understand the basic laws and language of the media as a kind of art, to develop aesthetic perception and taste); semiotic (authors hide the symbolic nature of their texts); critical (formation of critical thinking) and culturological (media offers, not imposes interpretation of texts) [31, p. 8-10]. Obviously, these theories determine the functional (causal) significance of media education, but do not fully reveal its basic characteristics, principles of construction, structuring as a modern educational paradigm that changes the educational and social reality.

As noted by I. Ziaziun, with participant age is characterized by the making of a new paradigm in philosophy and theory of education are an interrelated and complicated and contradictory variety of principles and conclusions, but their common lays in practical implementation of the newest ideas and concepts in education practice" [32, p. 22]. So public demand for the introduction of media education in all universities, regardless of their professional orientation and specialization associated with the need to prepare media competency and competent staff, which formed not only skills and intelligent information needs, but also new paradigms of thinking. Thus, new time requires the development of advanced media education programs primarily for students of higher educational institutions of both humanitarian and technical direction, which would be based on the capture of not only educational, psychological but also sociological and information theory also. In our opinion, it is expedient to introduce a special course in "Media Education and Smart Information Needs", the purpose of which may be: to form students' understanding of their information needs and requests; gaining knowledge about the content of medical products and social networks; acquiring the ability to understand, critically rethink and identify the destructive and manipulative goals of actors who shape media content on social networks; developing skills to confront them, as well as to create constructive media products in response to the challenges of the global information world.

The main content modules can be the following: "Information challenges and risks of the global world", "Smart information needs and their structure", "Nature and social nature of the Internet space", "Media market and its structure" and "Social communications in the network in the world", which explain not only the structure and content of the information and media market but also reveal the deep mechanisms of human information needs, including intelligent, the specifics of the convergence of virtual 
and real contacts, form an adequate understanding of media content and focus on its reasonable perception, and the ability to face the challenges and risks of the modern information world. Saturation of the special course with sociological knowledge will promote the formation of sociological thinking, which in students of higher education, including technical, "provides the accumulation of data in memory, necessary and sufficient for the formation of such paradigms of thinking that allow them to find the best solutions in the professional sphere [33].

The introduction of a media education course in the proposed format will contribute to the formation of reasonable information needs in modern students, which should be defined as such forms of their interaction with media (Internet, media, etc.), which meet their cognitive interests and pragmatic and rational inquiries to recognize misinformation and obtain truthful, useful and relevant information, the acquisition of information competence, which are necessary for the development of successful life strategies in today's globalized world, full of various challenges.

\section{CONCLUSIONS}

The temporality of the modern world, including its saturation of information technology, media products, as well as a variety untrue information, including fake, manipulation, on the necessity for the formation of young people, particularly students, intelligent information needs.

This problem is exacerbated by the fact that, according to sociological research among student youth in Ukraine and Poland, the Internet has become an everyday tool for meeting almost all other needs, including communication, which are moving into cyberspace. Almost two thirds of the surveyed higher education students spend up to 6 hours a day on the Internet, and a third of them spend more than 8 hours a day. This threatens not only the real living space of students, but also their health. Therefore, the problem of forming reasonable information needs in today's globalized world becomes especially relevant.

The novelty of this scientific work is to clarify the content, nature, structure, principles and factors of the concept "reasonable information needs" and their empirical verification. The author's proposal to consider reasonable information needs as such needs of the person in the necessary information which are realized by it, correspond to certain personal and social purposes, are socially significant and useful for its self-development, social relations and social behavior is substantiated. They are characterized by usefulness, rationality, expediency, consumer awareness, and the goal is to obtain new knowledge necessary for the realization of personal interests, which are associated with the satisfaction of reasonable needs and contribute to the formation of successful life strategies.

The paper substantiates the idea that in modern conditions the formation of reasonable information needs can occur due to various agents of socialization: family, teachers, friends, the media, and so on. The first important step towards understanding the rational information needs of future students can be STEM education, the acquisition of which in secondary schools will form in them the need for critical thinking, the ability to differentiate their interests in relation to information requests. In higher education institutions of both humanities and technical profile, the most important factor in the formation of reasonable information needs of students, we are convinced, is media education.

Media education already has its own history and its own traditions in many countries, particularly in Poland and Ukraine, but needs improvement in its plane intelligent adaptation of students in modern information space, forming their skills conscious manipulation of a plurality of information produced by the various mass media and forming personal first, the group and social media culture and as a factor and the development of the general culture of modern human.

However, the new times require new approaches to its implementation. We believe that in today's realities media education is not just one of the areas of education, and acquires the status of basic first educational and paradigms and, which is based on an interdisciplinary approach (philosophical, pedagogical, psychological and sociological) enables professional and educational training of the specialists of the new post-industrial era, who are able to consciously search for media products and critically comprehend its goals and content, to resist destructive manipulation technologies, to rationally and creatively build their professional activities.

Therefore, further scientific research in the field of forming reasonable information needs of young people and finding effective ways to form them in the higher education system is promising.

\section{REFERENCES}

[1] A.H. Maslow, A theory of human motivation, in: Psychological Review 50 (4) (1943) 370-396. 
[2] L.V. Konoval, Information needs: essence and definitions (Informatsiina potreba: sutnist ta definitsii),

2014. http://conference.nbuv.gov.ua/report/view/id/35 0

[3] A.M. Panina, Information need as a component of information culture of personality (Informatsiina potreba yak skladova informatsiinoi kultury osobystosti), 2013. https://mdgu-

kid.at.ua/publ/informacijna potreba jak sklado va informacijnoji kulturi osobistosti/1-1-0-65

[4] P. Borlund, N. Pharo, A need for information on information needs, Information Research 24 (4) (2019) colis1908. http://InformationR.net/ir/244/colis/colis1908.html

[5] Reasonable needs (Razumnye potrebnosti), Psychological encyclopedia, 2021. https://wiki.1vc0.ru/enciklopediya/razumnyepotrebnosti.html

[6] O.O. Stashkevich, The role of intellectual triplets in personality development, Humanitarian Bulletin ZDIA 57 (2014) 201-211.

[7] T. Wilson, On User Studies and Information Needs, Journal of Documentation 62 (6) (2006) 658-670.

[8] O.V. Kurnosenko, STEM - Osvita: problemy ta napriamky vprovadzhennia, 2020. http://tsiurupynsk-

school2.edukit.kherson.ua/distancijne navchann ya/mo vchiteliv fizikomatematichnih_nauk/stemosvita_problemi ta_napryamki_vprovadzhennya /

[9] D. Bachynsky, Media education in the system of modern educational institutions: domestic and foreign experience, Pedagogical education: theory and practice 25 (2018) 19-25.

[10] O.O. Demyanenko, Evolution of scientific research in the field of media education: critical thinking of the individual as the main component of modern media education, Narodna osvita 1 (31) (2017). https://www.narodnaosvita.kiev.ua/?page id=43 $\underline{89}$

[11] The Youth MediaLab project will be launched for Ukrainian schools,

2020. society/2742440-dla-ukrainskih-skil-zapustatproekt-youth-media-lab.html

[12] D. Dutsyk, The first textbook on media education and media literacy was presented to Ukraine, 2020.

https://ms.detector.media/mediaprosvita/books/u _dopomogu_mediapedagogam/

[13] The concept of introducing media education in Ukraine, 2020. https://ms.detector.media/mediaprosvita/mediao svita/kontseptsiya vprovadzhennya mediaosviti v ukraini/

[14] L.A. Naydonova, M.M. Slyusarevsky (Eds.), The concept of providing mediaosviti in Ukraine (new edition), Institute of Social and Political Psychology of the National Academy of Pedagogical Sciences, Kyiv, 2016.

[15] Internet Stats and Facebook Usage in Europe, 2019.

https://www.internetworldstats.com/stats4.htm\# europe

[16] Internet penetration in Ukraine, 2019. https:/inau.ua/sites/default/files/file/1910/dani ustanovchyh_doslidzhen_iii_kvartal_2019_roku. pdf

[17] V. Vorona, M. Shulga (Eds.), Ukrainian society 1992-2010. Sociological monitoring, Institute of Sociology of the National Academy of Sciences of Ukraine, Kyiv, 2010.

[18] Internet in Ukraine, 2020. https://uk.wikipedia.org/wiki/Internet_in_Ukrain e

[19] M. McLuhan, Understanding Media: The Extension of Man, McGraw-Hill Education, London and New York, 1964.

[20] V. Vorona, M. Shulga (Eds.), Ukrainian society 1992-2013. Status and dynamics of changes. Sociological monitoring, Institute of Sociology of the National Academy of Sciences of Ukraine, Kyiv, 2013.

[21] V. Vorona, M. Shulga (Eds.), Ukrainian society: monitoring of social change, vol. 6 (20), Institute of Sociology of the National Academy of Sciences of Ukraine, Kyiv, 2018.

[22] Ya.V. Zoska, A.O. Bessarab, Consumer intentions of Ukrainians regarding Internet content and services, Sotsialni tekhnolohii: 
aktualni problemy teorii ta praktyky 80 (2018) 61-72.

[23] A.Yu. Ishchenko, Modern media education: implementation in Ukraine and international experience, Strategic priorities 4 (2014) 80-84.

[24] J. Marcus, Putin's hybrid war is a NATO headache, 2014. https://www.bbc.com/news/world-30273813

[25] T. Popova, Social networks, cyberattacks and hybrid wars, 2017. https://www.radiosvoboda.org/a/28598299.html

[26] A.G. Stadnyk, S.S. Shcherbina, The use of political advertising in the process of information wars: a sociological aspect, Sotsialni tekhnolohii: aktualni problemy teorii ta praktyky 85 (2020) $32-43$.

[27] G.V. Onkovich, Theory of media education, Masova komunikatsiia: istoriia, sohodennia, perspektyvy 1 (2012) 29-33.

[28] L. Korotayevsky, In 2018, there were 4 billion Internet users, of which more than 3 billion use social networks - a study, 2018. https:/hromadske.ua/posts/u-2018-internetkoristuvachiv-stalo-4-mlrd-z-nih-ponad-3-mlrdkoristuyutsya-socmerezhami-doslidzhennya

[29] I. Kogut, Y. Stadny, M. Kudelia, T. Zheriobkina, I. Samokhin, Students' socio-economic portrait: survey results, 2016. https://cedos.org.ua/en/articles/sotsialnoekonomichnyi-portret-studentiv-rezultatyopytuvannia

[30] L. Masterman, A Rational for Media Education, in: R. Kubey (Ed.), Media Literacy in the Information Age, Transaction Publishers, New Brunswick \& London, 1997, pp. 15-68.

[31] V. Ivanov, O. Volosheniuk, L. Kulchytska, Media education and media literacy: a brief review, AUP TsVP, Kyiv, 2011.

[32] I.A. Zyazyun, Educational paradigms and pedagogical technologies in the dimensions of the philosophy of education, Naukovyi visnyk Mykolaivskoho derzhavnoho universytetu imeni V. O. Sukhomlynskoho. Seriia: Pedahohichni nauky 1.33 (2011) 22-26.

[32] A. Lobanova, Wiedza Socjologiczna jako czynnik paradygmatów myślienia u studentów na uczeleniach technicznych, in: A Kuzior (Eds.),
Humanistyka, Politechnika Sliaska Zabrze, 2015, pp. 108-115. 